\title{
SMALL-SCALE MINES, THEIR CUMULATIVE ENVIRONMENTAL IMPACTS AND DEVELOPING COUNTRIES BEST PRACTICE GUIDELINES FOR WATER MANAGEMENT
}

\author{
R. G. M. Heath
}

Pulles Howard \& de Lange (Inc), P O Box 861, Auckland Park, South Africa, 2006

\begin{abstract}
Small-scale mining occurs on a sizeable scale in many developing countries throughout the world. Active measures are undertaken by governments to promote the development of this mining sector for the promotion of the economy. The development of this sector does not bode well for the environment, as this sector is largely internationally unregulated.
\end{abstract}

The challenge is to manage small-scale mining in an environmentally acceptable manner, and by so doing, develop appropriate implementation and environmental management strategies. These strategies must be relevant, understandable, affordable, be aimed at maintaining a balance between encouraging economic developments and preserving high standards of environmental management. Various strategies for managing the water-related impacts caused by small-scale mining have been developed in South Africa. These government initiatives have focused on two levels namely, the small-scale miners themselves as well the regulators.

Through on going consultation between the regulators and small-scale miners and a continued education programme with documentation produced in South Africa, these initiatives will assist in the reduction of diffuse pollution impacts of current and future small-scale mining practises in developing countries.

\section{KEYWORDS}

Education; mining; pollution; public consultation; regulation; small-scale; water.

\section{INTRODUCTION}

Small-scale mining occurs on a sizeable scale in many developing countries throughout the world. Active measures are being taken by South African government to promote the development of the small-scale mining sector of the economy, especially in a sector of the population that previously had no access to the mineral resources of the country (White Paper, 1998). Similarly, the recently promulgated Minerals and Petroleum Resources Development Act, 2002 (Act 28 of 2000) (MPRDA) recognizes the need to promote local and rural development and the social upliftment of communities affected by mining.

The development and success of small-scale mining projects in South Africa (typical to any developing country) is presently limited by problems associated with access to mineral rights; access to finance; lack of appropriate structures that assist with development; operations that are located far from major markets; lack of management; marketing and technical skills. Furthermore, new small-scale mine operators face technical barriers to participate in mining, including lack of skills in dealing with aspects such as complex metallurgical processes, practical mining problems and business skills. The small-scale mining sub-sector can currently offer little security, such as security of tenure. 
The development of this sector, however, does not bode well for the environment, as this sector is largely internationally unregulated. The sustainable success of this sector depends largely governments providing these miners with technical assistance.

\section{Definition of small-scale mining}

There is no set definition of what is meant by a small-scale mine. The definition of small-scale mining varies depending on the purpose for which the term is being used. In terms of legislation and control of mining activities it is important that small-scale mining is defined and that appropriate legislation can be applied. The working definition used in South Africa is based on the amount of material moved per annum, on the number of employees and on the level of mechanization (Heath et al. 2002):

- A defined upper limit where the mine must not move more than 600000 tonnes material/annum (50 000 tonnes/month) or when the total area disturbed by mining activities is restricted to approximately 10 ha at closure.

- All small-scale mining types ranging from artisanal mines to small companies excluding junior companies (junior companies $=$ companies employing between 50 and 200 employees). This includes companies who are classified as micro ( $<5$ employees) to very small $(<20$ employees $)$ to small ( $<50$ employees).

- The level of mechanisation will also be used where micro-scale mining refers to artisanal mining that involves no mechanisation and whose prime motivation is subsistence; medium-scale smallscale mining where mining is not subsistence orientated and involves mechanisation on a limited scale (one truck, one front-end loader and a mechanical pan/washer); to large-scale small-scale mining that is not subsistence oriented and involves the use of extensive mechanical equipment (several trucks, front-end loaders and mechanical equipment for the processing of ore, MEPC, 1998).

\section{Types of small-scale mining in South Africa}

Typically the mining types that are considered to be small scale include diamond diggings, sand winning (dry-pit mining, wet pit mining, bar skimming and mining of pits on adjacent floodplains or river terraces), coal mining, gold mining/panning and alluvial gold deposits, clay mining and peat extraction.

\section{ENVIRONMENTAL IMPACTS OF SMALL SCALE MINES}

The type of mine, method of mining and refinement of extracted material have varied impacts on the environmental. For example small-scale coal mining has a large environmental impact irrespective of mine size due to the potential for the production of acid mine drainage from the pyrite exposed during mining.

In southern Africa, the most important environmental impacts caused by small-scale miners appear to be related to (Heath et al. 2002):

- Accelerated erosion of areas adjacent to workings that have been de-vegetated for construction materials or fuel wood leads to increased suspended sediment loads in nearby streams and rivers.

- Excavation of flood terraces and riverbanks increases the instability of these riverbanks and enhances the likelihood of increased flood scouring.

- $\quad$ Alteration of river channels and flows due to mining of alluvial deposits in the riverbed. 
- Excavation of river sediments exposes these sediments to oxidising conditions and enhances the solubility and release of any metal ions that may previously have been previously trapped as insoluble sulphides.

- $\quad$ Acid mine drainage and associated water quality problems in receiving waters.

- Gold panning and operation of sluice boxes increases loads of suspended sediments in downstream reaches.

- Wash-off of mercury used to concentrate gold leads to increased risks of mercury toxicity to aquatic and terrestrial organisms, as well as to the miners.

- Wind-blown dusts from unprotected tailings and waste rock dumps enter aquatic environment.

Singly, many of the effects of small- scale mining on the water environment may well be non-significant, however, when they occur simultaneously, their significance may increase by orders of magnitude. The overriding principle is that the greater the number of small-scale mines in an area, the greater the cumulative impacts are on the water environment. The major cumulative impacts include:

- $\quad$ Loss of riparian habitat due to large areas of riparian vegetation being removed.

- $\quad$ Riverbank destabilisation after vegetation removed.

- $\quad$ Soil erosion of arable land adjacent to mined areas.

- Increased surface areas of discard (sand, rock and other forms of waste) that can be mobilised during rain and ultimately are deposited in the rivers.

- Increased mobilisation of sediments, which become available and clog the aquatic environment.

- Increased incidents of oils (from machinery) and chemical (if refinement takes place) spills into rivers.

- Increased potential of mobilization of metals, sulphates, acid mine drainage and other possible toxicants (such as arsenic).

- $\quad$ Loss of arable land due to no rehabilitation.

- $\quad$ Large tracts of land becoming a safety hazard (for people and livestock).

The duration of these impacts are mainly long term or forever. For example, many areas along the Vaal and Orange Rivers were mined a century ago and the environmental degradation footprints are still prevalent. Unless appropriate rehabilitation takes place in areas that are on the riverbanks, the land largely remains unusable unless the area is naturally restored by for example, floods. The mining that takes place within the riverbed or flood plain has more chance of being restored back its original status over time due to floods.

The majority of the impacts from small-scale mines are diffuse in nature and are consequently different to manage unless appropriate mining methods are undertaken at the onset of the mining activity.

\section{Perceptions and knowledge of small scale miners on environmental legislation}

Structured interviews were conducted with small-scale miners and local communities in the major mining areas of South Africa in order to determine the knowledge and perceptions of theses sectors of environmental issues as a result of mining (Heath et al. 2002). The results of this survey can be summarised as follows:

- $\quad$ Communities living in close proximity to small-scale mining operations are aware of issues such as rehabilitation and the environmental impacts associated with mining activities.

- $\quad$ Mining is seen as a viable form of a living

- Environmental issues and impacts were largely ignored by the miners

- The required mining legislative documentation were seen as a "license to mine only" and were largely not consulted further for rehabilitation and closure 
- The local communities would prefer to become employed in the mining sector rather than become employed in the rehabilitation of small-scale mines.

- The regulators had difficulty in visiting, least of all regulating, the vast number of small scale mining operations.

- $\quad$ The regulators concentrated on the more formal larger scale mining operations.

\section{MANAGEMENT OPTIONS FOR MIMIMISING ENVIRONMENTAL IMPACTS OF SMALL-SCALE MINES}

The challenge in environmentally managing small-scale mining is to develop appropriate implementation strategies and environmental management systems. These strategies must be relevant, understandable, and affordable to the small-scale miner and should aim at maintaining a balance between encouraging economic developments and preserving high standards of environmental management. Various strategies for managing the water-related impacts caused by small-scale mining have been developed in South Africa. These government initiatives have focused on two levels, namely the small-scale miners themselves as well the regulators.

During a study undertaken by Heath et al. (2002) various strategies for managing the water-related impacts caused by small-scale mining were identified and include:

- Improved and harmonized legislation

- Governmental structure and mining laws

- $\quad$ Education and training

- $\quad$ Capacity building

- Collaboration forum and co-ordination

- Technical support and appropriate technology

- $\quad$ Best practice guidelines

- Improved stakeholder participation in decision-making

\section{Best Practice Guidelines for water quality management of mining}

Best Practice Guidelines (BPG's) for water quality management relating in the South African mining industry are in the process of being developed, in a consultative process, between regulators, miners and communities by the Department of Water Affairs and Forestry (DWAF). These BPG's address issues that range from water and salt balances to small-scale mine management.

Pro-active management of environmental impacts is required from the outset of mining activities in order to reduce this risk. Both DWAF and the mining industry have made major strides in the last few years in developing strategies and management plans for the effective management of water within the industry. This has largely been achieved through the development of joint structures where problems have been discussed and addressed through co-operation.

DWAF has the philosophy - PREVENTION BEFORE CURE and has developed a set of steps that helps the miner to prevent problems before they become more serious and need to be repaired:

- $\quad$ STEP 1: Prevent or minimise pollution or waste.

- STEP 2:If you cannot prevent water pollution, $\underline{\text { re-use }}$ wastewater or water that contains waste rather than disposing of it.

- STEP 3:If you cannot re-use the water, treat the wastewater so that you can re-use it before considering disposing of it. 
- $\quad$ STEP 4: Steps 1 to 3 may not be enough to prevent the discharge or disposal of wastewater. It may be that the quality of the polluted water still exceeds the applicable wastewater standards. In such a case you need to apply for a phased water use license containing:

- Extensive motivation for the water use authorisation, explaining social, financial and environmental implications.

- Firm commitment with a time schedule within which you will work towards achieving the specified water quality objectives.

The disposal or discharge of water containing waste, which exceeds the applicable standards, will only be considered as a last resort and as an interim measure.

In most cases a small-scale mine will cover its water pollution problems in Steps $\mathbf{1}$ and 2. If a small-scale miner needs to move on to Steps 3 and 4, they are recommended to consult a water treatment professional.

The BPG's also perform the following functions within the water management policy:

- $\quad$ Provide guidance on how to comply with Steps 1-3 as stated above

- Will be used by DWAF as a basis for evaluating licence applications and for drafting licence conditions

- Will serve as a uniform basis for negotiations through the licensing process prescribed by the National Water Act, 1998 (Act 36 of 1998) with the mining industry

- $\quad$ The mining industry as a guideline as to what the DWAF considers as best practice in water quality management.

The knowledge contained in the BPGs is transferred to interested parties through a structured technology transfer process, which includes the following steps:

- Workshops in key mining regions open to all interested parties, including representatives from the mining industry, government and the public.

- Provision of material to mining industry training groups for inclusion into standard employee training programmes.

- Provision of material to tertiary education institutions for inclusion into existing training programmes.

- $\quad$ Provision of hardcopy BPGs to interested parties in a format that can be updated as and when required.

- $\quad$ Provision of electronic BPGs on the DWAF's Internet web page.

\section{Best Practise Guideline for small-scale miners}

As recognition of the important role of small-scale miners in the South African mining industry, two BPG's were specifically written (Pulles et al., 2002 a and b). These BPG's documents will specifically assist the small-scale miners and the regional regulatory authorities that deal with the small-scale miners. These guidelines were developed by a task team and reviewed by workshops of specialists within and outside the mining industry and government. This particular guideline is prepared in two versions, namely a Standard format aimed at officials viz. water pollution control officials and environmental management personnel (Pulles et al., 2002 a) and a User format aimed at the small-scale miners, produced in English, Sotho and Zulu (Pulles et al., 2002 b).

This BPG describes typical small-scale mining scenarios and develops generic integrated assessment procedures (Figure 1). It uses a constructivist approach to detail regulatory requirements and procedures, the water management hierarchy, operational implementation and management. This BPG enables the 
small-scale mining to identify the legal regulations, basic measures that need to prevent and minimize impact on water resources; as well as water pollution prevention and minimization measures at each stage of the life cycle of a mine (Table 1, Pulles et al., 2002 b). It also aims to ensure consistency in the approach of the DWAF from mine to mine, and region to region and thus encourage uniformity in licence conditions (Pulles et al., 2002 a).

\section{INTRODUCTORY HANDBOOK FOR SMALL-SCALE MINERS}

During the study undertaken by Heath et al., (2004) a stakeholder workshop allowed delegates to give new input on the content and structure of a handbook that was produced to assist small-scale miners to mine responsibly (WRC, 2004). This guideline is a colourful, user-friendly document, with helpful illustrations and is freely available for small-scale miners to use.

In order to ensure that the contents of the WRC (2004) handbook is implemented in a consistent manner in South Africa a series of workshop were convened with the aim of educating miners and regulators on implementation strategies and to give them an understanding of the water-related issues of small-scale mining.

\section{CONCLUSIONS AND RECOMMENDATIONS}

In order to reduce the water-related impacts of small-scale mines, the following tools and processes are recommended:

- The small-scale miners are trained to mine in an environmental responsible manner, especially those that are applying to mine for the first time.

- $\quad$ The legislative requirements are made more accessible and understandable prospective small-scale miners.

- The water quality impacts of small-scale miners are monitored on a regional (large-scale) rather than on an individual mine basis.

Table 1: List of general do's and don'ts for small-scale miners (Pulles 2002b)

\begin{tabular}{|c|c|c|}
\hline \multicolumn{3}{|c|}{ As a Small-Scale Miner } \\
\hline \multirow[t]{11}{*}{ DO } & $\sqrt{ }$ & Apply for the necessary permits and authorizations \\
\hline & $\sqrt{ }$ & Plan your mining operations and camp site before you start mining \\
\hline & $\sqrt{ }$ & $\begin{array}{l}\text { Minimise access roads/paths into the river } \& \text { put in erosion protection } \\
\text { measures }\end{array}$ \\
\hline & $\sqrt{ }$ & Use only one access road to the river at a time \\
\hline & $\sqrt{ }$ & Control run-off and erosion \\
\hline & $\sqrt{ }$ & Put in storm water drainage trenches to divert clean storm water from site \\
\hline & $\sqrt{ }$ & Collect and treat dirty water from your operations \\
\hline & $\sqrt{ }$ & $\begin{array}{l}\text { Leave a buffer zone i.e. strip of natural area between the mine site and the } \\
\text { body of water of at least } 100 \mathrm{~m}\end{array}$ \\
\hline & $\sqrt{ }$ & Store oil, fuel \& chemicals safely in designated area outside of the buffer zone \\
\hline & $\sqrt{ }$ & Locate toilets outside of the buffer zone \\
\hline & $\sqrt{ }$ & Keep topsoil for rehabilitation \\
\hline
\end{tabular}




\begin{tabular}{|c|c|c|}
\hline \multicolumn{3}{|c|}{ As a Small-Scale Miner } \\
\hline & $\sqrt{ }$ & Keep topsoil separate from other soil/waste rock material \\
\hline & $\sqrt{ }$ & Protect topsoil by keeping in a secure bunded area on high ground \\
\hline & $\sqrt{ }$ & Stabilize pit walls \\
\hline & $\sqrt{ }$ & Stabilize banks and beds of a river \\
\hline & $\sqrt{ }$ & Rehabilitate as you go-it will save you time, energy and money \\
\hline & $\sqrt{ }$ & Backfill ponds, pits or roads created \\
\hline & $\sqrt{ }$ & Leave area as you found it \\
\hline \multirow{9}{*}{ DON'T } & $\mathbf{X}$ & Do not wait to rehabilitate till the very end \\
\hline & $\mathbf{X}$ & Do not leave waste rock piles behind \\
\hline & $\mathbf{X}$ & Do not leave pits open- they are a safety hazard and cause ponding \\
\hline & $\mathbf{X}$ & Do not remove vegetation from the river or river banks without replacing it \\
\hline & $\mathbf{X}$ & Do not dam up the river \\
\hline & $\underline{X}$ & $\begin{array}{l}\text { Do not mix topsoil and other soils or waste rock- keep separate for } \\
\text { rehabilitation }\end{array}$ \\
\hline & $\mathbf{X}$ & $\begin{array}{l}\text { Do not allow loose soil removed to wash away or blow away- keep covered } \\
\text { and place in a secure location }\end{array}$ \\
\hline & $\mathbf{X}$ & Do not use toxic chemicals for processing - there are other safer alternatives \\
\hline & $\mathbf{X}$ & Do not mine illegally \\
\hline
\end{tabular}

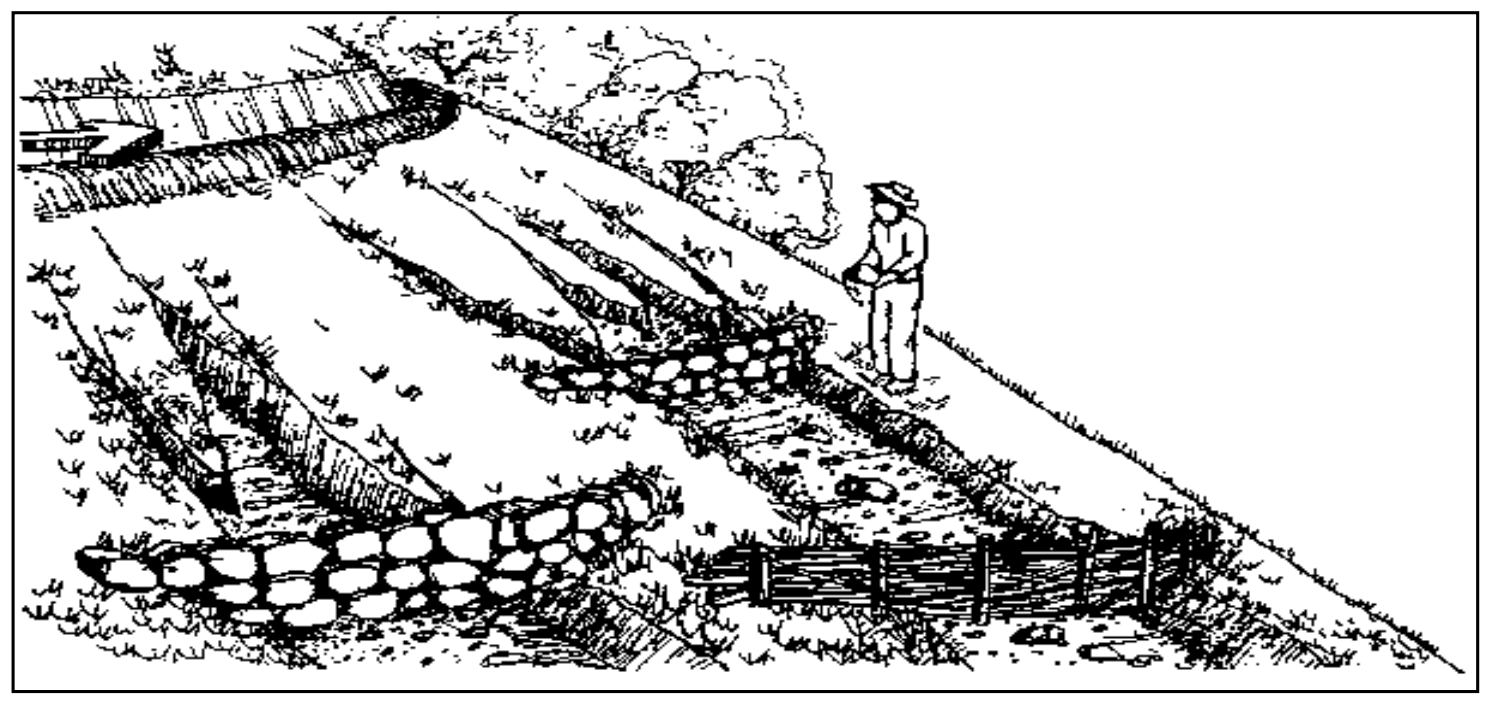

Figure 1: Contour diversion ditch and energy breaks for gully control (Pulles et al., 2002 b)

Through on going consultation between the regulators and small-scale miners we believe that the education programme and documentation as produced in South Africa will assist in the reduction of diffuse pollution impacts of future mining practises in developing countries. 


\section{REFERENCES}

Department of Minerals and Energy (1998). White Paper. A Minerals and Mining Policy for South Africa.

Pulles, W., Bannister, S, and Heath, R.G.M. (2002a). Prevention and Management of Water Pollution from Small-Scale Mining Practices (Standard Format). Department of Water Affairs and Forestry, 2002. Best Practice Guideline No. 2.1a

Pulles, W., Bannister, S, and Heath, R.G.M. (2002b). Prevention and Management of Water Pollution from Small-Scale Mining Practices (User Format). Department of Water Affairs and Forestry, 2002. Best Practice Guideline No. 2.1b

Heath, R. G. M., Moffett M. and Banister S. (2004). Water related Impacts of Small- Scale Mining WRC Report No. 1150/1/04

Minerals and Energy Policy Centre. (1998). The Status of Small-Scale Mining in South Africa.

Water Research Commission. (2004). Environmentally responsible mining - water management guideline for small-scale mining. WRC Report No. TT 170/4. Pretoria. 